\title{
High permissivity of the fish cell line SSN-1 for piscine nodaviruses
}

\author{
T. Iwamoto ${ }^{1}$, K. Mori ${ }^{2}$, M. Arimoto ${ }^{2}$, T. Nakai ${ }^{1, *}$ \\ ${ }^{1}$ Fish Pathology Laboratory, Faculty of Applied Biological Science, Hiroshima University, Higashihiroshima 739-8528, Japan \\ ${ }^{2}$ Kamiura Station, Japan Sea-Farming Association, Oita 879-2602, Japan
}

\begin{abstract}
Seventeen isolates of piscine nodavirus from larvae or juveniles of 13 marine fish species affected with viral nervous necrosis (VNN) were examined for their infectivity to a fish cell line SSN-1. Based on cytopathic effects (CPE) and virus antigen detection by fluorescent antibody technique (FAT) after incubation at $25^{\circ} \mathrm{C}$, the infectivity of these virus isolates was divided into 4 groups. Group 1 , including 9 virus isolates from 4 species of grouper, 2 species of sea bass, barramundi, rock porgy, and Japanese flounder showed CPE characterized by rounded, granular cells with heavy cytoplasmic vacuoles within $3 \mathrm{~d}$ post-incubation (p.i.), and the monolayer partially or completely disintegrated over 3 to $6 \mathrm{~d}$ p.i. Scattered FAT-positive cells appeared at $3 \mathrm{~h} \mathrm{p}$.i. and spread through the cell sheet with an increasing fluorescence signal over 24 h p.i. Group 2, consisting of 3 virus isolates from striped jack, induced CPE with thin or rounded, granular, refractile cells without conspicuous vacuole formation, and extensive FAT-positive reaction was observed in a time course similar to that of Group 1 Cells inoculated with Group 3 ( 1 isolate from tiger puffer) developed no distinct CPE but viral infection was evidenced by localized FAT-positive cells. There were no FAT-positive cells in Group 4, which included 4 isolates from Japanese flounder, Pacific cod and Atlantic halibut. However, when incubation was performed at $20^{\circ} \mathrm{C}$, the SSN-1 cells inoculated with the Group 3 isolate showed CPE similar to that of Group 1 and extensive FAT-positive reaction. Evidence of virus proliferation at $20^{\circ} \mathrm{C}$ was also obtained in Group 4 isolates. The virus titers in the infected fish varied from $10^{11}$ to $10^{16}$ tissue culture infectious dose $\left(\mathrm{TClD}_{50}\right)_{\mathrm{g}^{-1}}$ of fish. There is a good correlation between these infectivities to the SSN-1 cells and the coat protein gene genotypes of the isolates. The present results indicate that SSN-1 cells are useful for propagating and differentiating genotypic variants of piscine nodavirus.
\end{abstract}

KEY WORDS: Nodavirus - Viral nervous necrosis - Viral encephalopathy and retinopathy SSN-1 cell line $\cdot$ FAT $\cdot$ RFLP $\cdot$ RT-PCR

\section{INTRODUCTION}

Viral nervous necrosis (VNN, Yoshikoshi \& Inoue 1990) or viral encephalopathy and retinopathy (VER, Office International des Epizooties 1997), caused by piscine nodavirus, has been reported in a variety of cultured marine fish species worldwide since it was first reported in 1990. At present, the reported host fish species amount to more than 19 in 10 families and the disease is spreading in the Indo-Pacific region, the Mediterranean, France and Scandinavia, as reviewed by Munday \& Nakai (1997). The disease usually occurs in larvae and/or juveniles, resulting in high mortality

\footnotetext{
- Corresponding author.

E-mail: nakaitt@ipc.hiroshima-u.ac.jp
}

rates, with a few exceptions where fish at grow-out stages were affected (Fukuda et al. 1996, Le Breton et al. 1997). Affected fish exhibit a range of neurological signs; the affected central nervous tissues and retina contain areas of necrosis with vacuolation and virus particles in the cytoplasm of the nerve cells.

Three causative viruses, designated as SJNNV (striped jack nervous necrosis virus), DIEV (Dicentrarchus labrax encephalitis virus) and LcEV (Lates calcarifer encephalitis virus), have been purified from affected striped jack Pseudocaranx dentex, sea bass $D$. labrax and barramundi L. calcarifer, respectively (Mori et al. 1992, Comps et al. 1994) and identified to the family Nodaviridae, which was previously composed of small icosahedral insect riboviruses (Garzon \& Charpentier 1991, Murphy et al. 1995). The piscine noda- 
virus is a non-enveloped, icosahedral particle and the genome is composed of bipartite, single-stranded, positive-sense RNA molecules with molecular weights of 1.0 and $0.49 \times 10^{6}$ Da for RNA1 and RNA2, respectively. RNA1 encodes an unstructural protein of $100 \mathrm{kDa}$, which is presumably RNA-dependent RNA polymerase, and RNA2 encodes 2 major coat proteins of 42 and $40 \mathrm{kDa}$ (Mori et al. 1992, Comps et al. 1994).

These viruses and other piscine nodavirus isolates that have not been fully characterized display serological and molecular homology (Munday et al. 1994, Nguyen et al. 1994, Nishizawa et al. 1995, Grotmol et al. 1997, Sideris 1997), but the infection mode of these nodaviruses is not necessarily consistent among their host fish species (Munday \& Nakai 1997). Our recent unpublished data also suggest that they might have different host specificity and thus different infection mechanisms. Some techniques such as enzyme-linked immunosorbent assay (ELISA), fluorescent antibody technique (FAT), reverse transcription-polymerase chain reaction (RT-PCR), and in situ hybridization (Arimoto et al. 1992, Nguyen et al. 1994, Nishizawa et al. 1994, Comps et al. 1996) have been developed to detect piscine nodavirus in diseased fish; however, until recently, these were performed only on a limited number of fish species, from which virus particles had already been successfully purified, as cited before. Moreover, a number of workers attempted to culture these nodaviruses using a variety of cell lines but were unsuccessful (Breuil et al. 1991, Mori et al. 1991, Munday et al. 1992, Nguyen et al. 1994, Grotmol et al. 1995). In view of this, the infection mechanisms of the causative virus in each host species or the epidemiology of the disease was only partly understood. Recently, however, Frerichs et al. (1996) succeeded in culturing a nodavirus from diseased sea bass Dicentrarchus labrax using a fish cell line, SSN-1, derived from striped snakehead fish Ophicephalus striatus (Frerichs et al. 1991). This opened a new phase of research, particularly for the comparison of virulence among virus strains from different sources and provided a useful tool for epidemiological purposes because of the advantage for quantitative analysis.

In order to know whether the SSN-1 cell line is susceptible to other piscine nodaviruses associating with VNN disease, we examined the infectivity to the SSN1 cells of 17 piscine nodavirus isolates collected from 13 host fish species in 5 countries from 1991 to 1999.

\section{MATERIALS AND METHODS}

Nodavirus isolates and virus preparation. Diseased larvae or juveniles of 13 marine fish species were used as sources of virus in this study (Table 1). These include redspotted grouper Epinephelus akaara, sevenband grouper E. septemfasciatus, kelp grouper $E$. moara, brownspotted grouper E. coioides, Japanese sea bass Lateolabrax japonicus, sea bass Dicentrarchus labrax, barramundi Lates calcarifer, rock porgy Oplegnathus punctatus, Japanese flounder Paralichthys olivaceus ( 3 isolates), striped jack Pseudocaranx dentex ( 3 isolates), tiger puffer Takifugu rublipes, Pacific cod Gadus macrocephalus and Atlantic halibut Hippoglossus hippoglossus which were collected during disease outbreaks with mass mortality from 1991 to 1999 in Japan, Thailand, Australia, Greece and Norway. These were diagnosed as VNN by RT-PCR and FAT, as described later. Whole body for larvae or brain and eyes for juveniles were homogenized with 9 volumes of Hanks' balanced salt solution (HBSS, Nissui Co. Ltd) and a small amount of sea sand under iced conditions, and then centrifuged at $1200 \times g$ for $10 \mathrm{~min}\left(4^{\circ} \mathrm{C}\right)$. The supernatant was filtered through a $0.22 \mu \mathrm{m}$ membrane filter and stored at $-80^{\circ} \mathrm{C}$ until used.

RT-PCR and RFLP analysis. Fish samples (whole body of larvae, brain and/or eyes of juveniles) were homogenized with $1 \mathrm{ml}$ of ISOGEN (Nippon gene Co. Ltd) and shaken with $0.2 \mathrm{ml}$ of chloroform. After being centrifuged at $10000 \times \mathrm{g}$ for $15 \mathrm{~min}$, aqueous phase was treated with $0.5 \mathrm{ml}$ of isopropanol and centrifuged. The precipitate was treated with $70 \%$ ethanol and centrifuged, and finally extracted RNA was dissolved in diethyl pyrocarbonate (DEPC)-treated water. RT-PCR amplification was carried out using primers (R3 and F2) designed for the T4 region $(430 \mathrm{bp}$ ) or primers (R3 and F1) for the $\mathrm{T} 2$ region $(870 \mathrm{bp}$ ) of the SJNNV coat protein gene, according to the method described previously by Nishizawa et al. (1994). The T4 region was used for diagnosis of diseased fish and the T2 for restriction fragment length polymorphisms (RFLP) analysis. For RFLP analysis, the PCR amplicons of the $\mathrm{T} 2$ region were incubated with restriction enzymes Hae III and Sau3A I at $37^{\circ} \mathrm{C}$ for $3 \mathrm{~h}$, and the results were examined by 3\% agarose (NuSieve 3:1 agarose, FMC) gel electrophoresis.

Cell culture and virus isolation. A fish cell line, SSN-1 (Frerichs et al. 1991), was used here. The SSN1 cells were cultured in a $25 \mathrm{~cm}^{2}$ tissue culture flask (Sumitomo Bakelite Co. Ltd) at $25^{\circ} \mathrm{C}$ using Leibovitz L-15 medium (Gibco) supplemented with $10 \%$ fetal bovine serum. The monolayer covering 70 to $80 \%$ of the flask was washed twice with HBSS and then $500 \mu \mathrm{l}$ of the virus filtrate was inoculated in the cell culture. After standing at $25^{\circ} \mathrm{C}$ for $1 \mathrm{~h}$, the flask was washed with HBSS and supplemented with L-15 medium (2\% FBS), and incubated at 25 or $20^{\circ} \mathrm{C}$. Cytopathic effects (CPE) were observed daily for 2 wk. For the FAT test, $100 \mu \mathrm{l}$ of the virus filtrate was inoculated in a $0.8 \mathrm{~cm}^{2}$ chamber of Lab-Tek chamber slide (Nunc) in which 
Table 1. Infectivity of piscine nodavirus isolates to SSN-1 cells. ND: not done

\begin{tabular}{|c|c|c|c|c|c|c|c|c|c|}
\hline \multirow{2}{*}{$\begin{array}{l}\text { Diseased fish } \\
\text { species }\end{array}$} & \multirow{2}{*}{$\begin{array}{l}\text { Isolate } \\
\text { no. }\end{array}$} & \multirow{2}{*}{$\begin{array}{l}\text { Isolation } \\
\text { year }\end{array}$} & \multirow[t]{2}{*}{ Country } & \multirow[t]{2}{*}{ Genotype } & \multicolumn{5}{|c|}{ Infectivity to $S S N-1$ cells } \\
\hline & & & & & Group & \multicolumn{2}{|c|}{ Viral growth ${ }^{b}$} & $\begin{array}{l}\mathrm{CPE}^{\mathrm{C}} \\
\text { type }\end{array}$ & $\begin{array}{l}\text { Virus } \\
\text { particles }^{\mathrm{d}}\end{array}$ \\
\hline $\begin{array}{l}\text { Redspotted grouper } \\
\text { (Epinephelus akaara) }\end{array}$ & RGOka94 & 1994 & Japan & RGNNV & 1 & +++ & +++ & A & + \\
\hline $\begin{array}{l}\text { Sevenband grouper } \\
\text { (E. septemfasciatus) }\end{array}$ & SGWak97 & 1997 & Japan & RGNNV & 1 & +++ & ++ & A & + \\
\hline $\begin{array}{l}\text { Kelp grouper } \\
\text { (E. moara) }\end{array}$ & KGOit97 & 1997 & Japan & RGNNV & 1 & +++ & ++ & A & + \\
\hline $\begin{array}{l}\text { Brownspotted grouper } \\
\text { (E. coioides) }\end{array}$ & BGTha99 & 1999 & Thailand & RGNNV & 1 & +++ & ++ & A & ND \\
\hline $\begin{array}{l}\text { Japanese sea bass } \\
\text { (Lateolabrax japonicus) }\end{array}$ & JSOit98 & 1998 & Japan & RGNNV & 1 & +++ & ++ & A & + \\
\hline $\begin{array}{l}\text { Sea bass } \\
\text { (Dicentrarchus labrax) }\end{array}$ & SBGre96 & 1996 & Greece & RGNNV & 1 & +++ & +++ & A & ND \\
\hline $\begin{array}{l}\text { Barramundi } \\
\text { (Lates calcarifer) }\end{array}$ & BaAus94 & 1994 & Australia & RGNNV & 1 & +++ & ++ & A & ND \\
\hline $\begin{array}{l}\text { Rock porgy } \\
\text { (Oplegnathus punctatus) }\end{array}$ & RPWak96 & 1996 & Japan & RGNNV & 1 & +++ & +++ & A & + \\
\hline $\begin{array}{l}\text { Japanese flounder } \\
\text { (Paralichthys olivaceus) }\end{array}$ & JFHir92 & 1992 & Japan & RGNNV & 1 & +++ & ++ & A & ND \\
\hline Striped jack & SJNag91 & 1991 & Japan & SJNNV & 2 & +++ & +++ & $\mathrm{B}$ & ND \\
\hline \multirow[t]{2}{*}{ (Pseudocaranx dentex) } & SJNag92 & 1992 & Japan & SJNNV & 2 & +++ & +++ & $B$ & ND \\
\hline & SJNag93 & 1993 & Japan & SJNNV & 2 & +++ & +++ & $\mathrm{B}$ & + \\
\hline $\begin{array}{l}\text { Tiger puffer } \\
\text { (Takifugu rubripes) }\end{array}$ & TPKag93 & 1993 & Japan & TPNNV & 3 & + & ++ & A & - \\
\hline Japanese flounder & JFIwa96 & 1996 & Japan & BFNNV & 4 & - & +++ & $\mathrm{B}$ & ND \\
\hline ( $P$. olivaceus $)$ & JFIwa98 & 1998 & Japan & BFNNV & 4 & - & +++ & $\mathrm{B}$ & + \\
\hline $\begin{array}{l}\text { Pacific cod } \\
\text { (Gadus macrocephalus) }\end{array}$ & PCHok96 & 1996 & Japan & BFNNV & 4 & - & ++ & C & - \\
\hline $\begin{array}{l}\text { Atlantic halibut } \\
\text { (Hippoglossus hippogloss }\end{array}$ & $\begin{array}{l}\text { AHNor96 } \\
\text { AS) }\end{array}$ & 1996 & Norway & BFNNV & 4 & - & + & $\mathrm{C}$ & - \\
\hline \multicolumn{10}{|c|}{$\begin{array}{l}\text { 'Intensity of viral growth was given as number of FAT-positive cells less than } 100(+), 100 \text { to } 1000(++) \text {, more than } 1000(+++) \\
\text { in } 0.8 \mathrm{~cm}^{2} \\
{ }^{c} \text { (A) CPE characterized by rounded, granular cells with vacuoles, (B) CPE characterized by thin or rounded, refractile, granular } \\
\text { Cells, (C) no CPE } \\
\text { dSpherical } 25 \mathrm{~nm} \text { particles in paracrystalline array arrangement or in membrane-bound vesicles }\end{array}$} \\
\hline
\end{tabular}

cells were 70 to $80 \%$ confluent, incubated at 25 or $20^{\circ} \mathrm{C}$ for a required period, and immuno-stained as below.

Fluorescent antibody technique (FAT). Cells in the chamber were washed 5 times with HBSS, dried for $5 \mathrm{~min}$, and fixed with methanol for $10 \mathrm{~min}$. An antiSJNNV rabbit serum employed in a previous study (Nguyen et al. 1996), which was raised against purified virions of SJNNV, was used for the detection of nodavirus antigens. Briefly, after rinsing with $10 \mathrm{mM}$ phosphate buffered saline (PBS, pH 7.4), the slides were incubated with the anti-SJNNV rabbit serum (1:100 dilution in $\mathrm{PBS}$ ) at $37^{\circ} \mathrm{C}$ for $30 \mathrm{~min}$. After rinsing with $\mathrm{PBS}$, slides were incubated with FITC (fluorescein isothiocyanate)-conjugated swine Ig to rabbit Ig (Dako) at $37^{\circ} \mathrm{C}$ for $30 \mathrm{~min}$. The slides were washed, mounted with buffered glycerin ( $\mathrm{pH}$ 9.2) and examined with a fluorescence microscope (Nikon EFD). Intensity of FAT signals was given as roughly estimated number of positive cells; + : less than $100,++: 100$ to 1000 , and +++ : more than 1000 in a chamber $\left(0.8 \mathrm{~cm}^{2}\right)$.

Titration of virus. Samples from 4 species of diseased fish, including sevenband grouper (SGWak97), striped jack (SJNag93), tiger puffer (TPKag93) and Japanese flounder (JFIwa98), were used to titrate virus in the whole fish or tissues. The virus filtrate was serially diluted 10 -fold with HBSS up to $10^{20}$ and inoculated into the SSN-1 cells that were pre-cultured in the Lab-Tek chamber slide, as described above. Four chambers were used for each dilution. During incubation at 25 and $20^{\circ} \mathrm{C}$, the FAT test was performed using the anti-SJNNV serum at $3 \mathrm{~d}$ post-incubation (p.i.) and the $50 \%$ tissue culture infectious dose (TCID $_{50}$ $\mathrm{g}^{-1}$ ) was determined by the method of Reed \& Muench (1938). 
Electron microscopy. SSN-1 cells infected with each of the 10 selected virus isolates were incubated at $25^{\circ} \mathrm{C}$ for RGOka94, SGWak97, KGOit97, JSOit98, RPWak96 and SJNag93, and at $20^{\circ} \mathrm{C}$ for TPKag93, JFIwa98, PCHok96 and AHNor96. After incubation for $3 \mathrm{~d}$, the cells were fixed in a $2.5 \%$ glutaraldehyde $/ 2 \%$ paraformaldehyde mixture ( $\mathrm{pH}$ 7.4), post-fixed with $1 \%$ osmium tetroxide and embedded in Quetol-812 (Oken). Thin sections were stained with $1 \%$ uranyl acetate and $1 \%$ lead citrate, then examined with an electron microscope (Hitachi H-600A) at $80 \mathrm{kV}$ accelerating voltage.

\section{RESULTS}

\section{RFLP analysis of the coat protein genes}

Based on the RFLP analysis of PCR amplicons by Hae III and Sau3A I, virus isolates were divided into 4 RFLP Types 1 to 4 (Fig. 1): 9 isolates (RGOka94, SGWak97, KGOit97, BGTha99, JSOit98, SBGre96, BaAus94, RPWak96, JFHir92: lanes 1 to 9) belong to Type 1, 3 isolates of striped jack (SJNag91, SJNag92, SJNag93: lanes 10 to 12 ) to Type 2, 1 isolate of tiger puffer (TPKag93: lane 13) to Type 3, and 4 isolates (JFIwa96, JFIwa98, PCHok96, AHNor96: lanes 14 to 17) to Type 4 . These RFLP profiles were compared with those expected from published sequences of the RNA2
T2 region of piscine nodaviruses, and as the result RFLP Types 1 to 4 were identified to the RGNNV (redspotted grouper nervous necrosis virus), SJNNV, TPNNV (tiger puffer nervous necrosis virus), and BFNNV (barfin flounder nervous necrosis virus) genotypes (Nishizawa et al. 1995), respectively.

\section{Virus isolation}

Based on the CPE observation and FAT test after incubation at $25^{\circ} \mathrm{C}$, each nodavirus isolate from different sources was divided into 4 groups ( 1 to 4 ) according to their infectivity to the cell line (Table 1). Group 1, including 9 nodavirus isolates from 4 species of grouper (RGOka94, SGWak97, KGOit97, BGTha99), 2 species of sea bass (JSOit98, SBGre96), barramundi (BaAus94), rock porgy (RPWak96), and Japanese flounder (JFHir92), showed CPE characterized by rounded, granular cells with heavy cytoplasmic vacuoles within $3 \mathrm{~d}$ p.i. (Fig. 2b) and the monolayer partially or completely disintegrated over 3 to $6 \mathrm{~d}$ p.i. (Fig. 2c). In some cases, unaffected cells consisting of a few different cell types formed a monolayer at 10 to $14 \mathrm{~d}$ p.i. (Fig. 2d). Scattered FAT-positive cells appeared at $3 \mathrm{~h}$ p.i. and spread through the cell sheet with an increasing fluorescence signal over $24 \mathrm{~h}$ p.i. (Fig. 3a,b). The strongest FAT-positive signal was
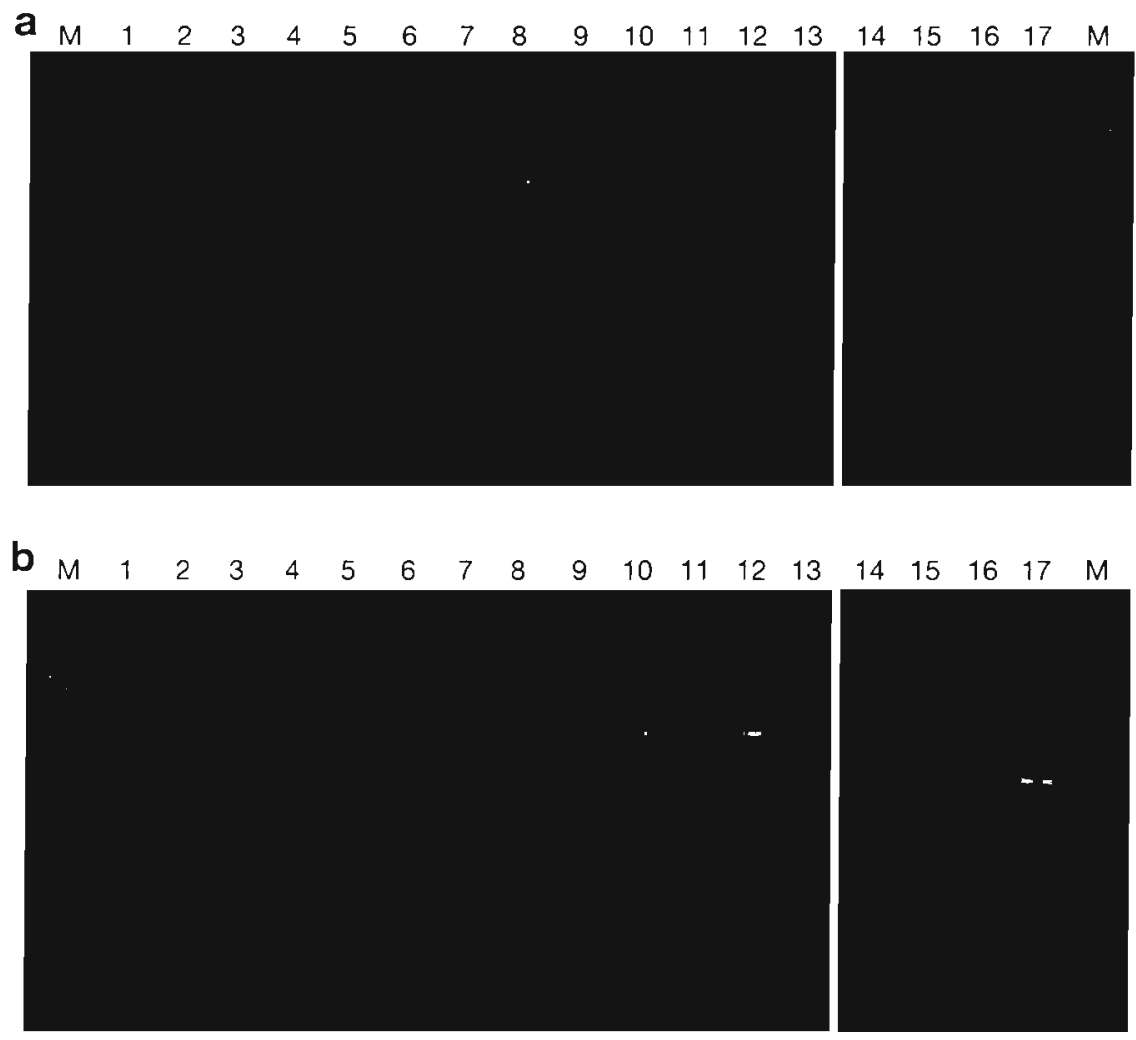

Fig. 1. RFLP profiles of nodavirus isolates. PCR amplicons of coat protein T2 region (870 bases) were treated with (a) Hae III or (b) Sau3A I. M: length marker ( $\phi \times 174$ Hae III digest); (1) RGOka94; (2) SGWak97; (3) KGOit97; (4) BGTha99; (5) JSOit98; (6) SBGre96; (7) BaAus94; (8) RPWak96; (9) JFHir92; (10) SJNag91; (11) SJNag92; (12) SJNag93; (13) TPKag93; (14) JFIwa96; (15) JFIwa98; (16) PCHok96; (17) AHNor96 

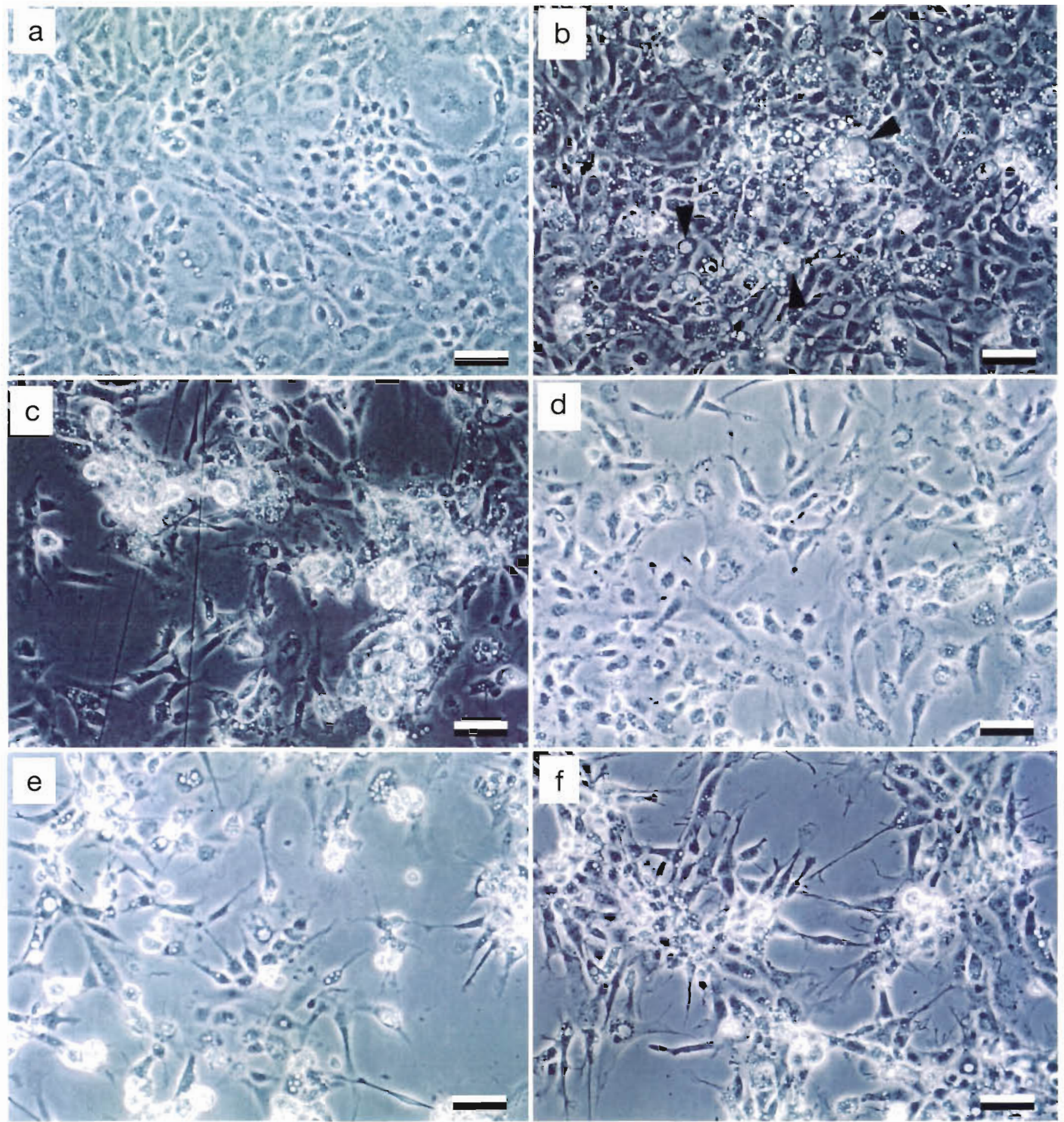

Fig. 2. Representative cytopathic effects (CPE) caused by nodavirus isolates in SSN-1 cells. (a) Normal SSN-1 cells, $3 \mathrm{~d}$ at $25^{\circ} \mathrm{C}$ (b) CPE by SGWak97 (Group 1), $3 \mathrm{~d}$ p.i. at $25^{\circ} \mathrm{C}$, (c) CPE by SGWak97, $7 \mathrm{~d}$ p.i. at $25^{\circ} \mathrm{C}$, (d) monolayer formation by unaffected cells after infection with SGWak97, $10 \mathrm{~d}$ p.i. at $25^{\circ} \mathrm{C}$, (e) CPE by SJNag93 (Group 2), $2 \mathrm{~d}$ p.i. at $25^{\circ} \mathrm{C}$, (f) CPE by JFIwa98 (Group 4), $3 \mathrm{~d}$ p.i. at $20^{\circ} \mathrm{C}$. Arrowheads indicate cytoplasmic vacuoles. Scale bars $=50 \mu \mathrm{m}$

detected at 72 h p.i. (Fig. 3e). Group 2, including 3 isolates (SJNag91, SJNag92, SJNag93) from striped jack only, exhibited CPE characterized by thin or rounded, granular, refractile cells within $3 \mathrm{~d}$ p.i., but the cytoplasmic vacuole formation was not so conspicuous as that in Group 1 (Fig. 2e). The cell sheet was 


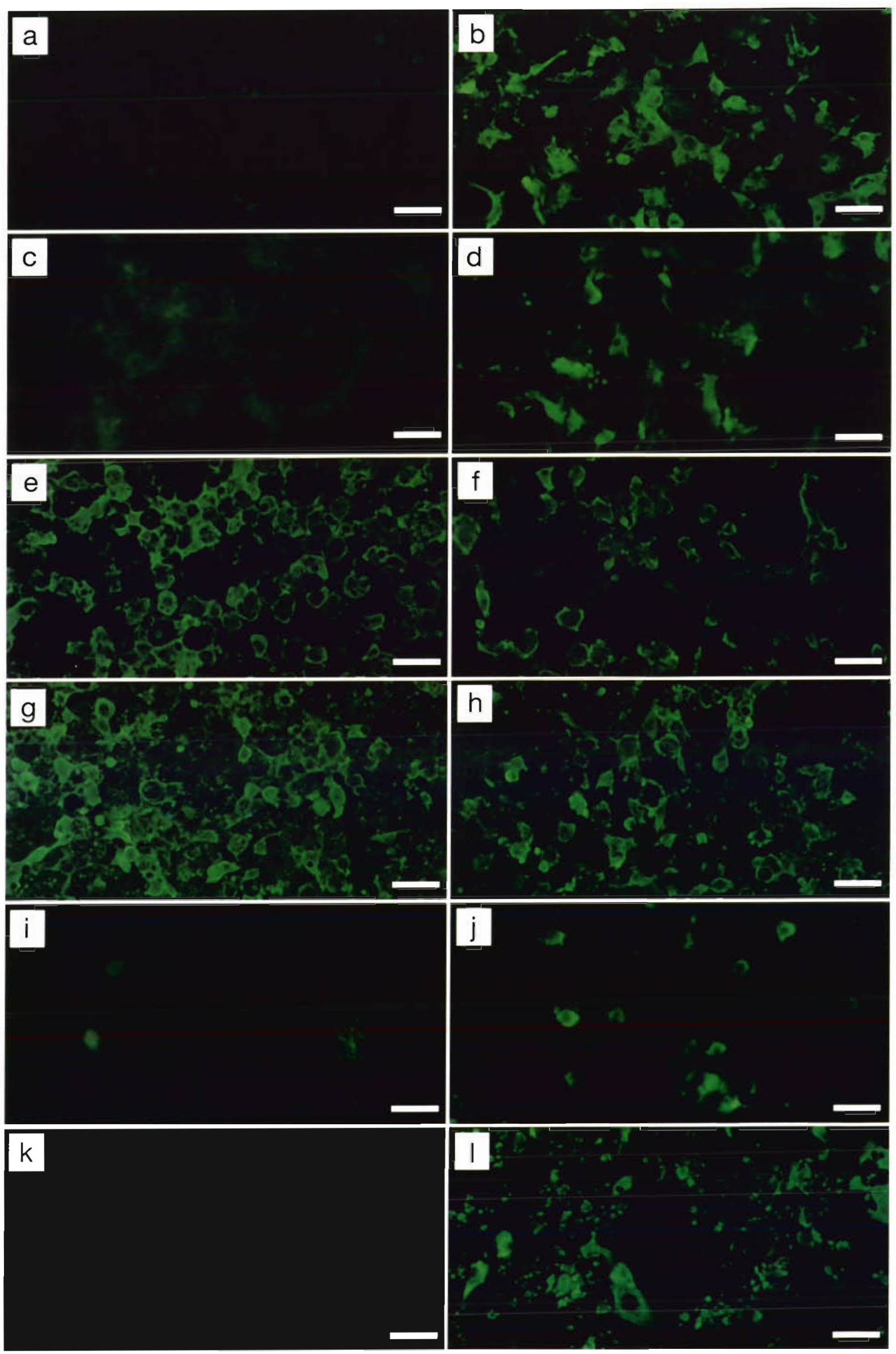


Fig. 3. Immuno-staining of SSN-1 cells infected with nodavirus isolates. Cells were inoculated with each virus isolate at 20 or $25^{\circ} \mathrm{C}$ and immuno-stained by FAT using rabbit anti-SJNNV serum. (a) SGWak97 (Group 1), 3 h p.i. at $25^{\circ} \mathrm{C}$; (b) SGWak97, $24 \mathrm{~h}$ p.i. at $25^{\circ} \mathrm{C}$ ( (c) SJNag93 (Group 2), 3 h p.i. at $25^{\circ} \mathrm{C}_{i}$ (d) SJNag93, 24 h p.i. at $25^{\circ} \mathrm{C}_{i}$ (e) SGWak97, 3 d p.i. at $25^{\circ} \mathrm{C}$; (f) SGWak97, 3 d p.i. at $20^{\circ} \mathrm{C}$; (g) SJNag93, 3 d p.i. at $25^{\circ} \mathrm{C}$; (h) SJNag93, 3 d p.i. at $20^{\circ} \mathrm{C}$; (i) TPKag93 (Group 3 ), 3 d p.i. at $25^{\circ} \mathrm{C}$; (j) TPKag93, 3 d p.i. at $20^{\circ} \mathrm{C}$; (k) JFIwa98 (Group 4), 3 d p.i. at $25^{\circ} \mathrm{C}$; (l) JFIwa98, 3 d p.i. at $20^{\circ} \mathrm{C}$. Scale bars $=25 \mu m(a, c)$ and $50 \mu m(b, d, e ~ t o ~ l)$

completely disintegrated at 3 to 5 d p.i. Weak FATpositive reaction was first observed in a broad area of cell sheet at $3 \mathrm{~h}$ p.i. and the fluorescence signal increased over $24 \mathrm{~h}$ to $3 \mathrm{~d}$ p.i. as in Group 1 (Fig. 3c,d,g). The CPE and FAT-positive reactions of both groups were reproduced after 3 passages of cellfree filtrate in the SSN-1 cell line. Group 3, 1 virus isolate from tiger puffer (TPKag93), developed no distinct CPE during a 14 d observation period but viral proliferation in cells was evidenced by the presence of localized FAT-positive cells over $24 \mathrm{~h}$ to $3 \mathrm{~d}$ p.i. (Fig. 3i). There were no FAT-positive cells in Group 4, which included 4 virus isolates (JFIwa96, JFIwa98, PCHok96, AHNor96) from Japanese flounder, Pacific cod and Atlantic halibut (Fig. 3k), though a slight CPE-like abnormality was observed in JFIwa96 and JFIwa98 isolates.

In incubation at $20^{\circ} \mathrm{C}$, the same but weaker CPE and FAT reactions as those observed at $25^{\circ} \mathrm{C}$ were observed in Group 1 and Group 2 virus isolates (Fig. 3f,h). The SSN-1 cells inoculated with TPKag93 isolate (Group 3) showed CPE similar to those in Group 1 at $25^{\circ} \mathrm{C}$ and extensive FAT-positive reaction at 5 to $6 \mathrm{~d}$ p.i. (Fig. 3j). Evidence of virus proliferation at $20^{\circ} \mathrm{C}$ was also observed in isolates of Group 4 by the positive FAT reaction (Fig. 31). Two isolates, JFIwa96 and JFIwa98, induced CPE similar to that in Group 2 (Fig. 2f) but such conspicuous CPE was not caused by PCHok96 and AHNor96. These CPE and/or FAT signals were reproducible after 3 passages in the SSN-1 cells.

\section{Electron microscopy}

Spherical virus particles $25 \mathrm{~nm}$ in diameter were observed in the cytoplasm of the SSN-1 cells inoculated with RGOka94, SGWak97, KGOit97, JSOit98, RPWak96, SJNag93 and JFIwa98, all of which exhibited +++ in FAT reaction (Fig. 4a to g), but not in TPKag93, PCHok96 and AHNor96, where FAT reactions were + or ++ . The virions were packaged in electron-dense inclusions consisting of virus particles arranged either in paracrystalline arrays or in membrane-bound vesicles. Apart from the small virions in the cytoplasm, formation and release of $90 \mathrm{~nm}$ diameter C-type retrovirus-like particles (Frerichs et al. 1991) were constantly observed in all cell cultures examined including nodavirus-uninfected control cells (Fig. 4h).

\section{Virus titration}

Virus titers $\left(\right.$ TCID $_{50} \mathrm{~g}^{-1}$ ) in 4 fish species that were obtained by FAT test following $3 \mathrm{~d}$ culture in SSN-1 cells are shown in Table 2. The virus titer of SGWak97 in sevenband grouper was extremely high $(1.7 \times$ $10^{16} \mathrm{TCID}_{50} \mathrm{~g}^{-1}$ ) when examined at $25^{\circ} \mathrm{C}$ but decreased to $3.2 \times 10^{9} \mathrm{TCID}_{50} \mathrm{~g}^{-1}$ at $20^{\circ} \mathrm{C}$, while those of SJNag93 in striped jack were $1.6 \times 10^{13} \mathrm{TCID}_{50} \mathrm{~g}^{-1}$ at $25^{\circ} \mathrm{C}$ and $6.8 \times 10^{9} \mathrm{TCID}_{50} \mathrm{~g}^{-1}$ at $20^{\circ} \mathrm{C}$. By contrast, the titers of TPKag93 in tiger puffer and JFIwa98 in Japanese flounder were considerably higher at $20^{\circ} \mathrm{C}$ than at $25^{\circ} \mathrm{C}$.

\section{DISCUSSION}

The SJNNV coat protein gene is 1410 bases long and contains a single open reading frame of 1023 bases (340 amino acids), and the sequence similarities between the coat protein gene of SJNNV and 4 known insect nodaviruses, Nodamura virus, black beetle virus, flock house virus and Boolarra virus (Murphy et al. 1995), are $10.6 \%$ or less at amino acid level, while a highly conserved sequence of $80.9 \%$ or greater is found in their T2 regions (ca 870 bases) among 5 Japanese isolates of piscine nodavirus (Nishizawa et al. 1995). High sequence similarity of the coat protein

Table 2. Titration of nodavirus in VNN-diseased fish using the SSN-1 cell line. Virus filtrate of diseased fish was serially 10 -fold diluted with HBSS and each dilution was inoculated onto SSN-1 cells and immuno-stained by FAT using rabbit anti-SJNNV serum $3 \mathrm{~d}$ after incubation at 25 or $20^{\circ} \mathrm{C}$

\begin{tabular}{|c|c|c|c|}
\hline \multirow[t]{2}{*}{$\begin{array}{l}\text { Diseased fish } \\
\text { species }\end{array}$} & \multirow[t]{2}{*}{$\begin{array}{l}\text { Virus isolate } \\
\text { (genotype) }\end{array}$} & \multicolumn{2}{|c|}{$\begin{array}{l}\text { Virus titer }\left(\mathrm{TCID}_{50} \mathrm{~g}^{-1}\right) \\
\text { obtained after incubation }\end{array}$} \\
\hline & & $25^{\circ} \mathrm{C}$ & $20^{\circ} \mathrm{C}$ \\
\hline Sevenband grouper & SGWak97 (RGNNV) & $1.7 \times 10^{16}$ & $3.2 \times 10^{9}$ \\
\hline Striped jack & SJNag93 (SJNNV) & $1.6 \times 10^{13}$ & $6.8 \times 10^{9}$ \\
\hline Tiger puffer & TPKag93 (TPNNV) & $1.7 \times 10^{5}$ & $4.3 \times 10^{11}$ \\
\hline Japanese flounder & JFIwa98 (BFNNV) & $<10^{2}$ & $3.2 \times 10^{12}$ \\
\hline
\end{tabular}



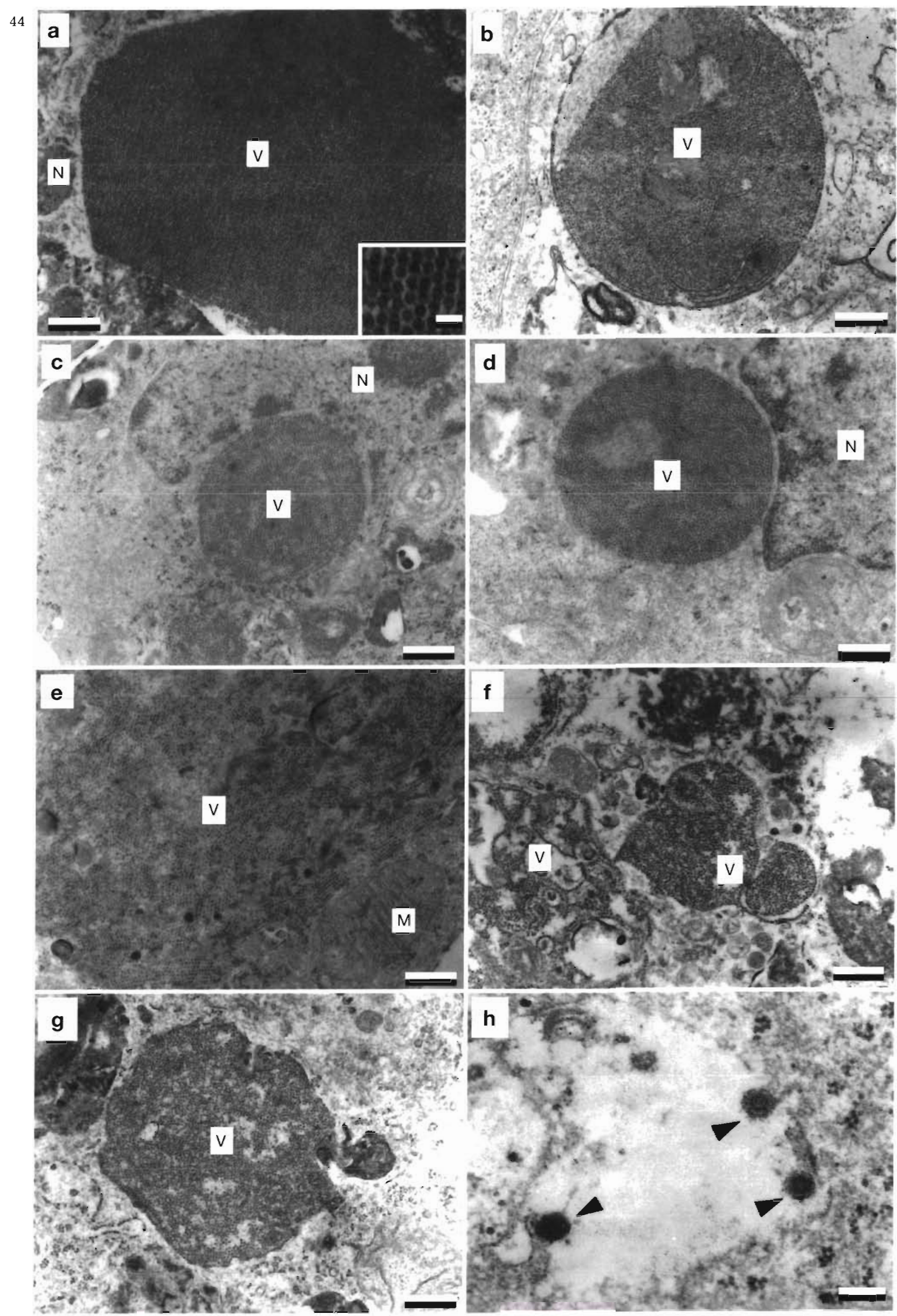
Fig. 4. Nodavirus and C-type retrovirus-like particles found in SSN-1 cells. After being inoculated with nodavirus isolates, cells were incubated at $25^{\circ} \mathrm{C}$ (a to $f, h$ ) or $20^{\circ} \mathrm{C}$ (g) for $3 \mathrm{~d}$. (a) SGWak97; (b) RPWak96; (c) KGOit97; (d) JSOit98; (e) JSOit98; (f) SJNag93; (g) JFIwa98; (h) C-type retrovirus-like particles (arrowheads) in a normal cell. Scale bars $=500 \mathrm{~nm}$ for (a to g), $50 \mathrm{~nm}$ for high magnification (a), and $100 \mathrm{~nm}(\mathrm{~h})$. V: nodavirus particles, $\mathrm{M}$ : mitochondria, $\mathrm{N}$ : nucleus

gene was also reported between these Japanese isolates and DlEV (Sideris 1997). Comps et al. (1996), using genomic RNA probes, demonstrated relatedness among RNA1 and RNA2 of nodavirus isolates from diseased sea bass (DlEV), barramundi (LcEV), turbot Scophthalmus maximus and shi drum Umbrina cirrosa. Although these results indicate close, genetic relatedness of piscine nodaviruses, an analysis of the variable region T4 ( 427 bases) in T2 revealed that 25 isolates of piscine nodavirus examined can be classified into 4 clusters: designated as TPNNV, SJNNV, BFNNV and RGNNV genotypes (Nishizawa et al. 1997). In the present study using 17 piscine nodavirus isolates which were collected from different sources, RFLP analysis of the $\mathrm{T} 2$ region proved to be useful for identifying these 4 genotypes. This is a rapid and simple method compared with sequence determination.

The present study demonstrated that the SSN-1 cell line is available for isolating and propagating all the piscine nodavirus isolates examined. Only 3 piscine nodaviruses (SJNNV, DIEV, LcEV) had been previously fully characterized as cited before, due to difficulties in purifying virus particles by differential centrifugation from diseased fish, particularly juvenile or older fish. Delsert et al. (1997) reported that DlEV was able to be propagated in 3 fish cell cultures (SBL, RTG-2, BF-2) and simian Cos 1 cells without CPE. However, the virus titration with SBL cells, the most permissive, resulted in relatively low yield with $10^{8}$ focus-forming units $\mathrm{ml}^{-1}$, indicating semipermissive expression of DIEV in these cells. In our study using SSN-1 cells and virus detection by FAT, the virus titers in infected fish were outstandingly high, though they varied from $10^{11}$ to $10^{16} \mathrm{TCID}_{50} \mathrm{~g}^{-1}$ (Table 2). Electron microscopy demonstrated vigorous virus multiplication in the cytoplasm of cells similar to that in nerve cells of naturally infected fish, though virus particles were not detected in the cells showing a moderate fluorescence signal $(++)$. This high productivity of virions indicates high permissivity of SSN-1 cells for piscine nodaviruses. We previously demonstrated in VNN of larval striped jack that the inoculum source of virus in larvae is the spawners, and the disease is prevented by eliminating virus-carrying fish from spawning groups after PCR diagnosis (Arimoto et al. 1992, Mushiake et al. 1994). However, PCR-based detection of virus from gonadal samples is not perfect and virus that escapes this elimination sometimes causes disease. From the present result of virus titer $\left(10^{13} \mathrm{TCID}_{50} \mathrm{~g}^{-1}\right)$ in striped jack larvae infected with SJNNV, it was roughly estimated that an infected striped jack larva (180 $\mu \mathrm{g}$ average weight) contained 1 billion infectious virions. This virus concentration determined by the culture method is consistent with that estimated from a bioassay method in which a $10^{13}$-fold diluted homogenate of $1 \mathrm{~g}$ of infected striped jack larvae was enough to cause VNN in healthy larvae (unpubl. data). Therefore, virus isolation with SSN-1 cells will be a useful method for detection of virus carriers and other epidemiological purposes or molecular analysis, because of its possible quantitative application. However, there are some disadvantages in the use of the SSN-1 cell line, particularly for molecular analysis: this cell line is composed of a mixed population of cells and is persistently infected by a C-type retrovirus (Frerichs et al. 1991, Hart et al. 1996). We are now attempting cloning of SSN-1 cells to overcome these problems

In the first isolation of a nodavirus from juvenile sea bass using the SSN-1 cell line, Frerichs et al. (1996) reported that CPE characterized by rounded, granular, refractile cells developed within $3 \mathrm{~d}$ of inoculation at $20^{\circ} \mathrm{C}$ before complete disintegration of the monolayer within about $10 \mathrm{~d}$. Although the genotype of the virus isolate used in their study is unknown, a sea bass isolate from Greece employed in the present study was proved to be the RGNNV genotype, and other isolates from diseased sea bass in Italy (Nishizawa et al. 1997) and Greece (Sideris 1997) had also been classified into the same genotype. In our study, the virus proliferation and resulting CPE were different among some virus isolates and depended on the incubation temperature. A good correlation was recognized between these cultural properties of virus isolates and their genotypes (RFLP analysis). Group 1, which consisted of 9 nodavirus isolates (RGOka94, SGWak97, KGOit97, BGTha99, JSOit98, SBGre96, BaAus94, RPWak96, JFHir92) that were identified to the RGNNV genotype, exhibited CPE with disintegration of cells and preferred 25 to $20^{\circ} \mathrm{C}$ for virus proliferation. Group 2 isolates, which were only from striped jack (SJNag91, SJNag92, SJNag93) and were identified to the SJNNV genotype, were able to proliferate well at both 20 and $25^{\circ} \mathrm{C}$ but the CPE was different from that in Group 1 because of a lack of heavy cytoplasmic vacuole formation. Vacuolation in the brain and retinal tissues, the most characteristic histopathological sign of VNN, was 
usually unclear in larvae of striped jack infected with SJNNV, compared with those in other fish species infected with other genotype nodaviruses. This may correlate with the above-mentioned difference in CPE found in the present SSN-1 cells. Group 3, which consisted of 1 virus isolate from tiger puffer (TPNNV genotype), exhibited very slight proliferation without $\mathrm{CPE}$ at $25^{\circ} \mathrm{C}$ but proliferated well with distinct CPE at $20^{\circ} \mathrm{C}$, and Group 4, which included 4 virus isolates (JFIwa96, JFIwa98, PCHok96 and AHNor96) identified to BFNNV genotype, only grew at $20^{\circ} \mathrm{C}$, suggesting a growth preference at lower temperatures. The results of virus titration (Table 2) supported this temperature dependency on virus proliferation in SSN-1 cells.

These differences in in vitro growth of virus isolates must correlate with their infectivity to fish, leading to host fish specificity. Natural infections by piscine nodaviruses occur in a wide range of rearing water temperatures, 28 to $30^{\circ} \mathrm{C}$ in brownspotted grouper (Danayadol et al. 1995), 25 to $28^{\circ} \mathrm{C}$ in sevenband grouper (Fukuda et al. 1996), 20 to $26^{\circ} \mathrm{C}$ in striped jack (Arimoto et al. 1994), 4 to $15^{\circ} \mathrm{C}$ in barfin flounder (Japan Sea-Farming Association 1995) and 6 to $7^{\circ} \mathrm{C}$ in Atlantic halibut (G. K. Totland pers. comm.). Data available to discuss the relationship between virulence of nodaviruses and rearing water temperature for fish are very limited. However, the results that the highest pathogenicity of SJNag92 (SJNNV genotype) from striped jack and SGMie95 (RGNNV genotype) from sevenband grouper was displayed at 24 and $28^{\circ} \mathrm{C}$, respectively (Arimoto et al. 1994, Tanaka et al. 1998) suggest that these 2 genotypes adapt to warm water conditions. On the other hand, our recent infection experiments (unpubl. data) suggest preference over lower water temperature of the BFNNV genotype: a BFNNV genotype isolate from Atlantic halibut was able to infect larval Atlantic halibut at $6^{\circ} \mathrm{C}$ but not larval striped jack at $20^{\circ} \mathrm{C}$ and, conversely, a SJNNV genotype isolate from striped jack was able to infect larval striped jack at $20^{\circ} \mathrm{C}$ but not larval Atlantic halibut at $6^{\circ} \mathrm{C}$. Although it cannot be ruled out that factors other than water temperature are involved in this phenomenon, the psychrophilic nature of the BFNNV genotype may explain why disease outbreaks under cold water conditions are limited only in this genotype of piscine nodavirus, suggesting that this will be due to temperature dependency of the RNA1 which probably encodes RNA-dependant RNA polymerase.

Acknowledgements. We thank G. N. Frerichs for providing SSN-1 celd line and S. Millar for his valuable advice on the cell culture. We also thank Y Danayadol, S. Grotmol, J. Glazebrook and S. Kiritsis for kindly providing the VNN-affected fish used in this study. This study was supported in part by a grant from the Japan Sea-Farming Association.

\section{LITERATURE CITED}

Arimoto M, Mushiake K, Mizuta Y, Nakai T, Muroga K, Furusawa I (1992) Detection of striped jack nervous necrosis virus (SJNNV) by enzyme-linked immunosorbent assay (ELISA). Fish Pathol 27:191-195

Arimoto M, Maruyama K, Furusawa I (1994) Epizootiology of viral nervous necrosis (VNN) in striped jack. Fish Pathol $29: 19-24$

Breuil G, Bonami JR, Pepin JF, Pichot Y (1991) Viral infection (picoma-like virus) associated with mass mortalities in hatchery-reared sea-bass (Dicentrarchus labrax) larvae and juveniles. Aquaculture 97:109-116

Comps M, Pepin JF, Bonami JR (1994) Purification and characterization of two fish encephalitis viruses (FEV) infecting Lates calcarifer and Dicentrarchus labrax. Aquaculture 123:1-10

Comps M. Trindade $\mathrm{M}_{t}$ Delsert Cl (1996) Investigation of fish encephalitis viruses (FEV) expression in marine fishes using DIG-labelled probes. Aquaculture 143:113-121

Danayadol Y, Direkbusarakom S, Supamattaya K (1995) Viral nervous necrosis in brownspotted grouper, Epinephelus malabaricus, cultured in Thailand. In: Schariff $M$, Arthur JR, Subasinghe RP (eds) Diseases in Asian aquaculture II Fish Health Section, Asian Fisheries Society, Manila, p 227-233

Delsert C, Morin N, Comps M (1997) Fish nodavirus lytic cycle and semipermissive expression in mammalian and fish cell cultures. J Virol 71:5673-5677

Frerichs GN, Morgan D, Hart D, Skerrow C, Roberts RJ, Onions DE (1991) Spontaneously productive C-type retrovirus infection of fish cell lines. J Gen Virol 72:2537-2539

Frerichs GN, Rodger HD, Peric Z (1996) Cell culture isolation of piscine neuropathy nodavirus from juvenile sea bass, Dicentrarchus labrax. J Gen Virol 77:2067-2071

Fukuda Y, Nguyen HD, Furuhashi M, Nakai T (1996) Mass mortality of cultured sevenband grouper, Epinephelus septemfasciatus, associated with viral nervous necrosis. Fish Pathol 31:165-170

Garzon S, Charpentier G (1991) Nodaviridae. In: Adams JR, Bonami JR (eds) Atlas of invertebrate viruses. CRC Press, London, p 351-370

Grotmol S, Totland GK, Kvellestad A, Fjell K, Olsen AB (1995) Mass mortality of larval and juvenile hatchery-reared halibut (Hippoglossus hippoglossus L.) associated with the presence of virus-like particles in the central nervous system and retina. Bull Eur Assoc Fish Pathol 15:176-180

Grotmol S, Totland GK. Thorud K, Hjeltnes BK (1997) Vacuolating encephalopathy and retinopathy associated with a nodavirus-like agent: a probable cause of mass mortality of cultured larval and juvenile Atlantic halibut Hippoglossus hippoplossus. Dis Aquat Org 29:85-97

Hart D. Frenichs GN, Rambaut A, Onions DE (1996) Complete nucleotide sequence and transcriptional analysis of the snakehead fish retrovirus. J Virol 70:3606-3616

Japan Sea-Farming Association (1995) Diseases of hatchery reared larvae and juveniles. Kyokai Kenkyu Shiryo 66 (in Japanese)

Le Breton A, Grisez L, Sweetman J, Ollevier F (1997) Viral nervous necrosis (VNN) associated with mass mortalities in cage-reared sea bass, Dicentrarchus labrax (L.). J Fish Dis 20:145-151

Mori K, Nakai T, Nagahara M, Muroga K, Mekuchı T, Kanno $T$ (1991) A viral disease in hatchery-reared larvae and juveniles of redspotted grouper. Fish Pathol 26:209-210

Mori K, Nakai T, Muroga K, Arimoto M, Mushiake K, Furusawa I (1992) Properties of a new virus belonging to 
Nodaviridae found in larval striped jack (Pseudocaranx dentex) with nervous necrosis. Virology 187:368-371

Munday BL, Nakai T (1997) Special topic review: nodaviruses as pathogens in larval and juvenile marine finfish. World J Microbiol Biotechnol 13:375-381

Munday BL, Langdon JS, Hyatt A, Humphrey JD (1992) Mass mortality associated with a viral-induced vacuolating encephalopathy and retinopathy of larval and juvenile barramundi, Lates calcarifer Bloch. Aquaculture 103: $197-211$

Munday BL, Nakai T, Nguyen HD (1994) Antigenic relationship of the picorna-like virus of the larval barramundi Lates calcarifer Bloch to the nodavirus of larval striped jack, Pseudocaranx dentex (Bloch \& Schneider). Aust Vet J 71:384

Murphy FA, Fauquet CM, Bishop DHL, Ghabrial SA, Jarvis AW, Martelli GP, Mayo MA, Summers MD (eds) (1995) Virus taxonomy - 6th report of ICTV. Virology Division, International Union of Microbiological Societies, SpringerVerlag, New York

Mushiake K, Nishizawa T, Nakai T, Furusawa I, Muroga K (1994) Control of VNN in striped jack: selection of spawners based on the detection of SJNNV gene by polymerase chain reaction (PCR). Fish Pathol 29:177-182

Nguyen HD, Mekuchi $T$, Imura $K$, Nakai $T$, Nishizawa $T$, Muroga K (1994) Occurrence of viral nervous necrosis (VNN) in hatchery-reared juvenile Japanese flounder Paralichthys olivaceus. Fish Sci 60:551-554

Nguyen HD, Nakai T, Muroga K (1996) Progression of striped jack nervous necrosis virus (SJNNV) infection in naturally

Editorial responsibility: Jo-Ann Leong,

Corvallis, Oregon, USA and experimentally infected striped jack Pseudocaranx dentex larvae. Dis Aquat Org 24:99-105

Nishizawa T, Mori K, Nakai T, Furusawa I, Muroga K (1994) Polymerase chain reaction (PCR) amplification of RNA of striped jack nervous necrosis virus (SJNNV). Dis Aquat Org 18:103-107

Nishizawa T, Mori K, Furuhashi M, Nakai T, Furusawa I, Muroga K (1995) Comparison of the coat protein genes of five fish nodaviruses, the causative agents of nervous necrosis in marine fish. J Gen Virol 76:1563-1569

Nishizawa T, Furuhashi M, Nagai T, Nakai T, Muroga K (1997) Genomic classification of fish nodaviruses by molecular phylogenetic analysis of the coat protein gene. Appl Environ Microbiol 63:1633-1636

Office International des Epizooties (OlE) (1997) Viral encephalopathy and retinopathy or viral nervous necrosis. In OIE (eds) Diagnostic manual for aquatic animal diseases. OIE, Paris, p 99-107

Reed IJ, Muench $\mathrm{H}$ (1938) A simple method of estimating fifty percent end points. Am J Hyg 27:493-497

Sideris DC (1997) Cloning, expression and purification of the coat protein of encephalitis virus (DIEV) infecting Dicentrarchus labrax. Biochem Mol Biol Int 42:409-417

Tanaka S, Aoki H, Nakai T (1998) Pathogenicity of the nodavirus detected from diseased sevenband grouper Epinephelus septemfasciatus. Fish Pathol 33:31-36

Yoshikoshi K, Inoue K (1990) Viral nervous necrosis in hatchery-reared larvae and juveniles of Japanese parrotfish, Oplegnathus fasciatus (Temminck \& Schlegel). J Fish Dis 13:69-77

Submitted: July 21, 1999; Accepted: October 6, 1999

Proofs received from author(s): December 15, 1999 